патологія представлена, і обрати правильний варіант. Після електронного голосування один з учасників дискусії описував кожне завдання зі своїми висновками. Представник “ареопагу” дає свою відповідь, а аудиторія - свою, перемагає той, чия відповідь буде найбільш правильною і влучною.

\section{Література}

1. Дисуринский А. Н. История образования и педагогической мысли : учебн. для студ. высш. учеб. завед. / А. Н. Дисуринский. - М. : Изд-во ВЛАДОС-ПРЕСС, 2004. - 400 с.

2. Орбинський В. Л. Педагогіка вищої школи : навч. посіб. / В. Л. Орбинський. -К. :Центручбовоїлітератури, 2009. -472 с.

3. Столяренко Л. Д. Педагогическая психология / Л. Д. Столяренко. - Ростов н/Д : Феникс, 2009. - 541 с.

4. Підаєв А.В. Болонський процес в Свропі. Що це таке і чи потрібен він Україні? Чи можлива інтеграція медичної освіти України в Свропейський освітнійпростір?/ А. В. Підаєв, В. Г. Передерій. - Одеса : Одес. держ. мед. ун-т, 2004. - 190 с.

5. Кузьмінський А. І. Педагогіка вищої школи : навч. посіб. / А. І. Кузьмінський. - К. : Знання, 2005. - 486 с. - (Вища освіта XXI століття).

6. Нові технології навчання менеджменту в медицині : навч. посіб. / за редакцією Ю. В. Вороненка, Н. Г. Гойди, О. П. Мінцера, М. Мітчела.- К. : Книга плюс, 2009. - 409 с.
Висновок. Таким чином, якісне післядипломне навчання лікарів можливе лише за умов безперервного навчання, що базується на усіх досягненнях світової медичної науки та використанні всіх сучасних освітянських технологій.

7. Новые педагогические и информационные технологии в системе образования : учебное пособие для студ. высш. учеб. заведений / Е. С. Полат, М. Ю. Бухаркина, М. В. Моисеева, А. Е. Петров. - [3-е изд.]. - М. : Издательский центр “Академия”, 2008. - 272 с.

8. Последипломное медицинское образование. Международные стандарты ВФМО улучшения качества . - УН-Т Копенгагена, 2003. - 32 с.

9. Организация индивидуально-ориентированного учебного процесса в системе зачетных единиц / [ред. Б. А. Сазонов] . - Москва: НИИВО, 2003. - 98 с.

10. Gragg B. (2007) Tools from the Field: Participant-Centered Techniques for Effective Training. John Snow, Inc. and World Education, Inc., Boston, Massachusetts, $130 \mathrm{p}$.

11. Hubbard J.P. (2001) Measuring medical education. Lea \& Febiger, Philadelphia, 971 p.

\title{
ДОСВІД ОРГАНІЗАЦІЇ НАВЧАЛЬНОГО ПРОЦЕСУ ЗА КРЕДИТНО- МОДУЛЬНОЮ СИСТЕМОЮ НА КЛІНІЧНИХ ДИСЦИПЛІНАХ У ДОНЕЦЬКОМУ БАЗОВОМУ МЕДИЧНОМУ КОЛЕДЖІ
}

\author{
О. В. Швидкий, К. М. Тарасенко, О. А. Хадикіна, В. С. Малиновська \\ Донечький базовий медичний коледж
}

\section{EXPERIENCE OF ORGANIZATION OF EDUCATIONAL PROCESS ACCORDING TO THE CREDIT-MODULAR SYSTEM IN CLINICAL DISCIPLINES IN DONETSK BASIC MEDICAL COLLEGE}

\author{
O. V. Shvydkyi, K. M. Tarasenko, O. A. Khadykina, V. S. Malynovska \\ Donetsk Basic Medical College
}

\begin{abstract}
У статті представлено аналіз п'ятирічного досвіду роботи 3 клінічних дисциплін Донецького базового медичного коледжу в умовах кредитно-модульної системи організації навчального процесу, наведено основні проблеми і шляхи удосконалення якості підготовки медичних фахівців.

The article presents the analysis of the five-year experience of clinical disciplines work in Donetsk Basic Medical College in the conditions of credit-modular system of educational process organization. It also shows the main problems and ways of improvement of quality of medical specialists' preparation.
\end{abstract}

Вступ. Реформування системи охорони здоров'я вимагає переглянути зміст медсестринської освіти, щоб

вона відповідала міжнародній системі, а саме зростанню роліпрофесійної підготовки медичних сестер [4].

() О. В. Швидкий, К. М. Тарасенко, О. А. Хадикіна, В. С. Малиновська 
Приєднання України до Болонського процесу змусило насамперед переосмислити структуру навчального процесу, запровадити кредитно-модульну систему (далі - КМС) навчання.

Основу КМС створює навчання, яке компонується на модульній основі із застосуванням інформаційних технологій навчання, з урахуванням індивідуальних особливостей тих, хто навчається.

За останні роки КМС достатньо досліджується вченими. Так, автори Т. Бєляєва, Ю. Бондарчук, Г. Чуйко, М. Шегедин, опираючись на дослідження взаємозв' язку навчальної діяльності, розглядають доцільність використання цієї моделі освіти [1-5]. Вони зазначають, що ця технологія поки ще оформлена на рівні ідеї та представлена авторськими педагогічними технологіями, на жаль, залишається недостатньо розробленою на рівні педагогічного проектування.

Пропонуємо ознайомитися 3 досвідом роботи педагогічного колективу Донецького базового медичного коледжу (далі - ДБМК) з питань впровадження кредитно-модульної системи навчання.

Основна частина. Кредитно-модульна система - це модель організації навчального процесу, підгрунтям якої є об'єднання модульних технологій навчання і залікових кредитів ECTS як одиниць виміру навчального навантаження студента, необхідного для засвоєння змістових модулів або блоку модулів.

Навчання в коледжі за умови кредитно-модульної системи здійснюється за навчальними та робочими навчальними програмами, де зміст дисциплін структуровано за модулями.

Організація навчання за КМС регламентується графіком навчального процесу. Згідно $з$ ним циклові комісії визначають термін вивчення модулів та проведення відповідних контрольних заходів, що фіксується в робочій програмі навчальної дисципліни і графіку модульного контролю.

Розглянемо особливості організації навчального процесу за кредитно-модульною системою в ДБМК. Така система передбачає:

- розподіл навчальної дисципліни на модулі, а оцінювання знань студентів за допомогою модульнорейтингового принципу. Уніфікованою одиницею виміру обсягу навчальної роботи студента є кредит, який дорівнює 30 годинам загального навчального навантаження на тиждень, 3 них 1/3 - позааудиторна самостійна робота студента;

- кожен модуль має свою дидактичну мету, перелік теоретичних та практичних завдань, об'єм самостійної роботи студентів;
- в рамках однієї навчальної дисципліни може бути не більш 6-8 модулів. Якщо дисципліна вивчається протягом одного семестру, кількість модулів становить 1-3.

Кожен модуль реалізується у вигляді лекцій, практичних занять та самостійної роботи студентів. Так, дисципліна "Медсестринство у внутрішній медицині" поділена на 9 модулів, “Громадське здоров’я і громадське медсестринство” - 2 модулі. Модулі структуруються на невеликі частини, що поєднуються за змістом. Вони мають назву - змістові модулі.

У кожному модулі визначені обов'язкова і варіативна частини.

1. До обов'язкової частини входять:

- лекції;

- практичні заняття;

- виконання позааудиторної самостійної роботи;

- підсумковий модульний контроль.

2. Варіативна частина включає:

- виступ на конференціях;

- участь у рольових та ділових іграх;

- робота професійного гуртка;

- написання рефератів;

- науково-дослідницька робота.

Вивчення кожного модуля починається з повторення головних знань та навичок попереднього модуля i закінчується систематизацією вивчених навичок i вмінь. Так, утворюється ядро знань модуля, що є основою знань 3 дисципліни. КМС передбачає під час лекцій проводити періодично поточний контроль за допомогою письмового опитування або тестового контролю. Під час проведення практичних занять при відпрацюванні практичних навичок викладачами застосовується робота зі студентами малими групами. Також студенти проводять самооцінку своєї навчальної діяльності, що дозволяє викладачам використовувати результати самооцінки студентів для більшої об'єктивності оцінювання знань та вмінь. Вивчення кожного модуля завершує модульний контроль, що проводиться на останньому занятті для діагностики досягнення мети навчання.

Оцінка за модуль визначається як сума оцінки поточної навчальної діяльності (у балах) та оцінки підсумкового модульного контролю. Студент оволодіває знаннями постійно, протягом семестру, а незаймається зубрінням перед іспитом. Зростає активність студентів на практичних та теоретичних заняттях, що пов' язане 3 переходом від пасивних до активних форм навчання. Змінюється форма спілкування між викладачем та студентом. Відносини викладач - студент формуються в атмосфері психологічного комфорту. 
При вивченні дисциплін “Медсестринство у внутрішній медицині”, “Громадське здоров'я і громадське медсестринство" впроваджується така послідовність організації навчального процесу:

1. На початку вивчення дисципліни викладач пояснює студентам особливості модульно-рейтингової системи навчання, ознайомлює 3 темами модуля, системою оцінювання знань.

2. Викладач забезпечує студентів матеріалами модуля, переліком обов'язкової та додаткової літератури, графіком проведення тестувань та модульного контролю практичних навичок.

3. Протягом семестру студент регулярно відвідує всі лекції, практичні заняття, передбачені навчальним планом і затверджені розкладом.

4. Студенти самостійно опрацьовують теоретичні матеріали та вдосконалюють практичні навички у тренажерному кабінеті.

5. На заняттях здійснюється поточний та підсумковий контролі. Форми проведення підсумкового контролю включають контроль теоретичної та практичної підготовки.

6. Враховуються додаткові бали, які складаються із виконання студентом самостійної роботи, відвідування тренажерного кабінету та творча робота студентів (участі у конференціях, конкурсах, олімпіадах, виготовленні фантомів тощо).

7. По завершенню модуля визначається сума балів, яку набрав студент під час теоретичних та практичних занять.

8. Рейтинг рівня знань студента з дисципліни - це середня арифметична кількість балів усіх модулів, яку він набрав.

9. Після цього проводиться конвертація рейтингу із традиційної 4-бальної у шкалу ECTS і ранжування студентів.

Оцінювання навчальних досягнень студентів відбувається на основі рейтингової системи. Розроблена у коледжі методика розрахунку рейтингу єдина для всіх навчальних дисциплін. В основу рейтингової системи оцінювання покладено накопичення балів за різнобічну навчально-пізнавальну діяльність студентів у процесі навчання.

При вивченні модуля студент може набрати максимальну кількість балів - 200б. Оцінка за модуль складається із суми оцінок теоретичних знань (80 балів) i практичних навичок (120 балів). До підсумкового модульного контролю 3 практики допускаються студенти, що засвоїли теоретичну частину модуля.

Після завершення вивчення дисципліни:

- проводиться підрахунок балів, які набрав студент;
- оцінка конвертується в оцінку шкали ECTS;

- складається рейтингова шкала успішності студентів.

У коледжі введена єдина комп'ютерна система обліку знань студентів, що дає можливість спроектувати систему внутрішнього моніторингу якості підготовки фахівців, це забезпечує об' єктивний діяльнісно-орієнтований контроль навчальних досягнень студентів.

Для підвищення мотивації та більш глибокого вивчення матеріалу з дисциплін "Медсестринство у внутрішній медицині”, “Громадське здоров'я і громадське медсестринство" викладачами коледжу використовується “кейс-метод".

"Кейс" - це навчально-методичне забезпечення кожного модуля:

- для аудиторної роботи: тексти лекцій, методичні розробки з практик;

- для контролю знань: тести, проблемні задачі, “німі” - схеми, фрагменти таблиць, міні-контрольні тощо;

- для позааудиторної самостійної роботи: методичні розробки та питання контролю знань. Результати самостійної роботи студентів обов' язково враховуються під час модульного контролю.

Кожен студент має кейс із всіх дисциплін, що вивчає. Важлива перевага "кейс-методу" - структуризація діяльності студента за логікою етапів засвоєння знань: сприйняття, розуміння, осмислення, запам'ятовування, застосування, узагальнення, систематизація, контроль і корекція.

Викладачі проводять вчасне коригування навчальної діяльності студента, що дає можливість в подальшому підвищити рівень знань 3 дисципліни. Студентам надаються додаткові індивідуальні консультації в час, відведений для самостійної роботи студентів. Викладачі направляють роботу студентів, що сприяє оптимальному результату. Спільними зусиллями викладача і самостійної роботи студента досягається конкретний результат у формуванні сучасного спеціаліста, у чому велику роль відіграє кредитно-модульна система навчання.

Доповнення, поглиблення та закріплення знань студентів відбуваються під час практики на базі лікувально-профілактичних установ. Підсумкова практика студентів з клінічних дисциплін, що вивчаються, та переддипломна практика теж проводяться за кредитно-модульною системою на базі відділень лікарень під контролем викладача.

Підсумкова практика студентів спеціальності “Сестринська справа”, на якій у коледжі застосовується кредитно-модульна система, складає один модуль. Переддипломна практика має структурований поділ з кожної клінічної дисципліни, а саме "Медсестринство 
у внутрішній медицині”, “Медсестринство в хірургії, "Медсестринство в педіатрії. Вона складається 3 3 модулів, до кожного $з$ яких входить по 2 змістових модулі. Це створює студентам найбільш сприятливе поле для успішного засвоєння навчальних дисциплін. Закріплює у свідомості молоді думку щодо безперервності процесу освіти як одного із найважливіших чинників конкурентоспроможності, самодостатності.

Висновки. Аналізуючи п'ятирічний досвід роботи в умовах кредитно-модульної системи, можна відзначити такі її переваги:

- забезпечує відкритість, прозорість, гнучкість, i демократичність освіти;

- допомагає студентам максимально якісно засвоїти навчальний матеріал за мінімальний термін;

\section{Література}

1. Бєляєва Т. Крок до Болонського процесу / Т. Бєляєва // Освіта в технікумі, коледжі. - 2007. - № 1 .

2. Бондарчук Ю. Удосконалення форм і методів навчання відповідно до вимог Болонського процесу / Ю. Бондарчук , Г. Чуйко, Н. Чуйко // Вища школа . - 2005. - № 2. - С. 35-42.

3. Корсар К. Свропейський простір вищої освіти і України в ХХІ столітті/К. Корсар //Вищашкола.-2005. - №1. - С.47-56.
- структурованість навчального матеріалу сприяє глибокому засвоєнню, запам' ятовуванню інформації, узагальненню знань під час постійного повторення;

- дозволяє використовувати комп'ютерні технології для поточного і підсумкового контролю знань;

- рейтингова система оцінювання стимулює діяльність студента на кінцевий результат;

- спонукає та навчає студентів працювати самостійно, постійно протягом семестру;

- студент - рівний учасник навчального процесу;

- враховуються індивідуальні здібності кожного студента;

- підвищує зацікавленість студентів через постійний контроль, гласність результатів і систему заохочень.

4. Шегедин М.Б. Медсестринство в Україні / М. Б.Шегедин .- Тернопіль: Укрмедкнига, 2006. - 280 с.

5. Матеріали до підсумкової колегії Міністерства освіти і науки України. Вища освіта України - європейський вимір : стан, проблеми, перспективи // Вища школа. - 2008. - № 4. C. 18-20. 